\title{
POST-DISASTER LEARNING MODEL: DESIGN OF DISTANCE LEARNING BASED ON LOCAL WISDOM PERSPECTIVE
}

\author{
Jaka Warsihna ${ }^{1}$, E. Oos M. Anwas², Zulfikri Anas², Fauzy Rahman Kosasih ${ }^{3}$ \\ and Zulmi Ramdani ${ }^{4}$ \\ ${ }^{1}$ Universitas Terbuka, Indonesia, Jalan Jendral Ahmad Yani, No 43, Jakarta \\ ${ }^{2}$ Center of Curriculum and Book, Ministry of Education and Culture, Indonesia, Jalan Gunung Sahari No 4, Jakarta \\ ${ }^{3}$ Universitas Terbuka, Indonesia, Jalan Jendral Ahmad Yani, No 43, Jakarta \\ ${ }^{4}$ Faculty of Psychology, UIN Sunan Gunung Djati Bandung, Jalan AH Nasution, No 105, Cibiru-Bandung, Indonesia
}

\begin{abstract}
The occurrence of disasters in certain areas resulted in drastic changes in the lives of the affected communities. It also has an impact on learning process which may not work properly. Damage to learning infrastructure, loss of student interest and motivation, and limited human resources after a disaster may be the factors that determine how quickly the community can rise up and recover from this situation. This study aims to create an adaptive post-disaster learning model that can be used to maintain the learning process optimally. The study employed qualitative research method with a research and development model. Observation activities, semi-structured interviews, and focus group discussions were conducted on a group of respondents consistent with the characteristics of the study. The results show that the post-disaster learning model should focus on existing resources in evacuee camps (local wisdom). This learning model can be achieved through optimizing existing teaching materials in the affected areas or by carrying out social fun activities while maintaining the achievement of learner's competence in certain subjects. Thus, this study provides an initial framework for explaining a suitable learning model that can be used in disaster-stricken areas.
\end{abstract}

\section{KEYWORDS}

Disaster, Local Wisdom, Learning Media, Distance Learning, Post-Disaster Learning

\section{INTRODUCTION}

Being in a complex geological zone, makes Indonesia one of the countries with rich natural resources. This contradictory condition also creates a great potential for the threat of disasters that may occur at any time (Pek, Kang and Anantharaman, 2019). Disasters that come unexpectedly often result in various losses even under certain conditions capable of paralyzing various sectors of human life, one of which is the education sector (James, 2014). When a disaster occurs, the education aspect is often a big concern of policy makers where they try to optimize this part, because it is considered very fundamental to the sustainability of the lives of the affected community.

Various natural disasters that have occurred to date usually have a tremendous impact not only on a person's physical and cognitive development, they can also disrupt the person psychological condition (Forbes, Creamer and Wade, 2012; Thurston et al., 2017). In the realm of education, natural disasters that occur in an area result in several unpleasant conditions, including damage to existing educational facilities and infrastructure, hindering accessibility and community services in affected areas, the learning process stops, and more seriously disturbs emotional stability of learners who experience it. This condition is not only felt by learners, teachers and other related parties are also the parts who must feel such conditions as well. By looking at such limited conditions, it is very unlikely that learning is carried out normally, so an adaptive learning model is needed that can be used after a disaster.

Post-disaster learning is an absolute thing that must be fulfilled, especially for learners who live in disaster-prone areas. This is necessary to prepare individuals to remain optimal in the learning process even in conditions that are full of limitations. Several studies have shown that post-disaster learning is very effective 
in recovering motivation, feelings of enthusiasm, struggling attitudes, life resilience, and perspectives for learners who are affected (Rusilowati and Binadja, 2012; Rahman and Umam, 2018; Susiana, 2018). Post-disaster learning itself focuses on an adaptive and flexible process that can be carried out at any time by involving the resources owned by the affected areas and also taking into account the psychological conditions of the individuals who experience it. Post-disaster learning can only be achieved when each individual collaborates to find the best adaptive model with the enthusiasm and sincerity of everyone to help together (Li, Wu and Wong, 2016; Robertson et al., 2019).

Studies that have been conducted in Indonesia show that the implementation of post-disaster learning is highly dependent on the model. Post-disaster learning is the main thing to pay attention to the psychological condition of the individual first so that when the individual is in a stable condition, this will make it easier for them to carry out post-disaster learning. Several examples of post-disaster learning are exemplified by Putri, Sanjoto and Sriyanto (2018) through a pocket book containing adaptive guidelines that can be carried out by disaster-affected communities. Kusmaryono (2012) also conducted a study that attempted to implement a technology-based learning that was able not only to contain learning content, but also to entertain the learners because of the content. In addition, post-disaster learning is carried out by identifying the advantages and possible benefits that can be obtained from the affected areas (Dewy, 2018).

The post-disaster learning model applies an open and distance learning (ODL) system. It refers to the flexibility of learning amid existing limitations (Hemsley, Holm and Dodd, 2013; Steinert et al., 2017). Learning can be effective in the midst of a disaster when everyone together helps each other according to their respective capacities. The flexibility that is present in the learning process does not allow individuals to learn without direction, in this case it is necessary to have individuals who really understand the advantages and disadvantages of the resources they have after a disaster. Ideal post-disaster learning not only gives learners the freedom to explore their environment just like that, but also prepares them to become agents of change in the future who will participate in volunteering for education in their environment. In addition, post-disaster learning has a broader urgency. In addition to providing local wisdom-based learning, it is also expected to be able to increase learner's participation to love their environment, form a stronger generation in the future, until the fulfillment of a control system that is fast and responsive to disasters around (Issa et al., 2019; Tsujiguchi et al., 2019).

Several previous studies have specifically explained that the post-disaster learning model is considered the most effective one to be used after a disaster ( $\mathrm{Li}$, Wu and Wong, 2016; Robertson et al., 2019). The majority of studies describe the model in a limited application or innovative activity which require a lot of money and take longer time to execute. Meanwhile, the individual learning process is an absolute thing that must be addressed immediately after a disaster, so that a more appropriate learning model is based on the potential and local wisdom in the affected areas. This study aims to focus on the potential of existing resources in disaster-affected areas, be able to provide effective and fun learning media, and become an integrated system with existing policy makers. Thus, the study aims to conduct an in-depth exploration of (1) Government and local community efforts in implementing education for learners affected by disasters; (2) Description of potential resources in the disaster-affected area; (3) The most suitable teaching resources model for learners in disaster-affected areas, and (4) The most effective learning model used after a disaster.

\section{METHOD}

The study was conducted using a research and development model. It is used to develop, refine, and validate the learning model which in this study focuses on a post-disaster learning design (Wang and Hannafin, 2005). The study adopted several steps for implementing this method by referring to several previous studies (Gall, Borg and Gall, 1996; Joseph, 2004; Wang and Hannafin, 2005), which can be seen in Figure 1. 


\begin{tabular}{|c|}
\hline -Previous Studies \\
\hline -Planning \\
\hline -Preliminary Model Development \\
\hline -Preliminary Field Testing \\
\hline -Model Revision \\
\hline -Model Testing to Users \\
\hline -Model Revision \\
\hline -Validity Test \\
\hline - Final Model Revision \\
\hline - Dissemination and Implementation \\
\hline
\end{tabular}

Figure 1. Post-Disaster Learning Development Procedure

Referring to the procedures in Figure 1, each procedure must certainly consider the validity and objectivity of the data collected so that it will affect the accuracy of the results. This study used a comprehensive frame of mind by providing a model built by a suitable method. The researchers conducted a case study by focusing on data collection in two areas affected by the earthquake in Indonesia, namely Palu-Southeast Sulawesi and Lombok-West Nusa Tenggara. Respondents who are involved in research were theoreticians who were tasked with conducting focus group discussions related to the study carried out, the policy makers in the affected areas as the parties who have the authority in the affected areas, make direct observations of the activities of the learners in the disaster-affected areas, as well as volunteers from surrounding community, teachers, and other activists who work in the disaster-affected areas.

To collect objective data, the researchers validated the activity process by maintaining applicable ethics and upholding human right values. All respondents who were involved in the research consciously and voluntarily took part in the activity until it was finished. The process of data analysis and interpretation of research results is carried out by referring to thematic content analysis that focuses on achieving results according to the objectives (Ramdani, Amrullah and Felisima Tae, 2019; Tae, Ramdani and Shidiq, 2019; Prakoso, Ramdani and Rahmah, 2020).

\section{RESULTS \& DISCUSSION}

To get a comprehensive picture of the facts in the field, the researchers present the results of the research by first giving the real conditions in the disaster-affected areas.
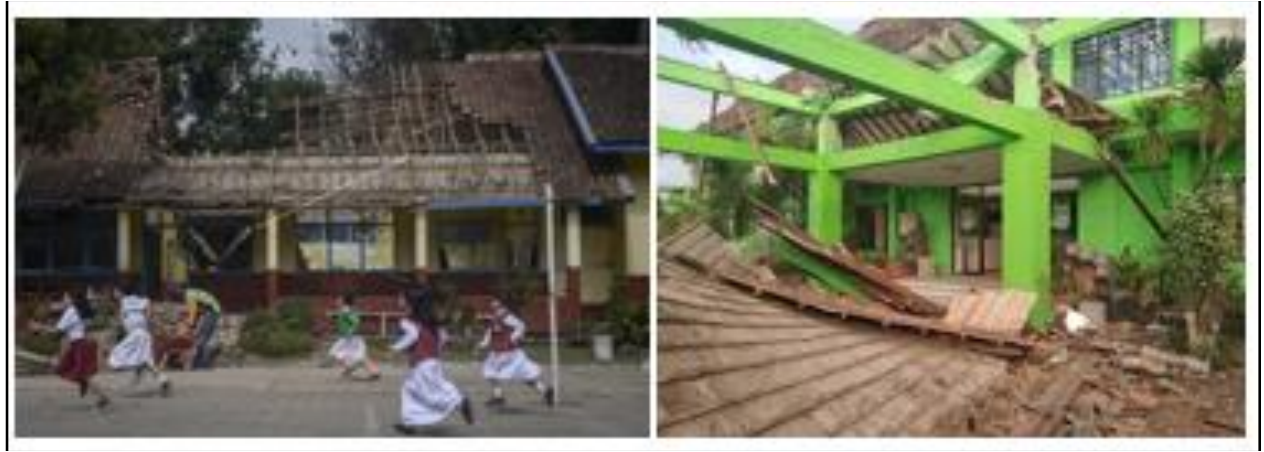

Figure 2. Post-Disaster Learning Infrastructure Condition 
Figure 2 presents a real picture of the damage to school infrastructure as a result of the earthquake that occurred in the affected areas. Many schools are paralyzed and cannot be operated due to inadequate conditions and may result in other physical threats, so by seeing these conditions the learning process is transferred outside of school and uses areas that are safer from previous damage. Furthermore, in a certain period of time the government together with the community built emergency schools which were considered to be an effective alternative in carrying out the learning process (see Figure 3).

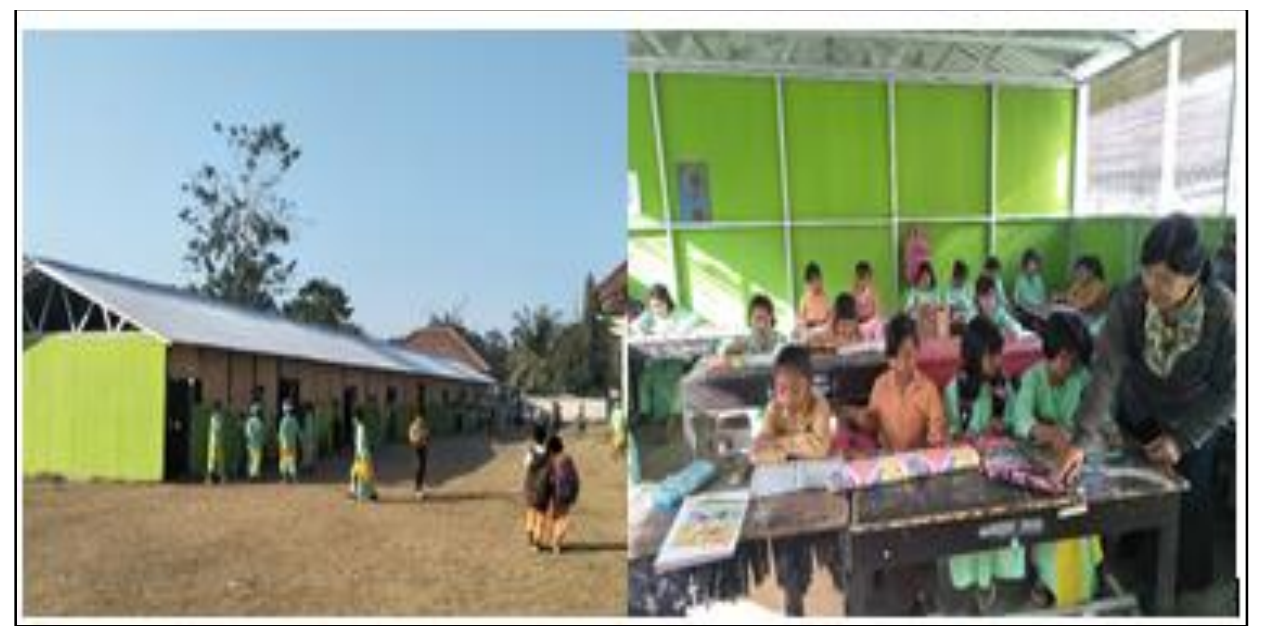

Figure 3. Learning Process in Emergency Schools

Emergency schools (see Figure 3), of course, were built to get an optimal learning process even though they were within the limitations. Emergency schools are an effective strategy that can be used as a place for individual development after a disaster. After the emergency school is built, post-disaster learning must certainly involve various stakeholders who are concerned about education development in the affected areas. One of them is to provide adaptive learning as shown in Figure 4.

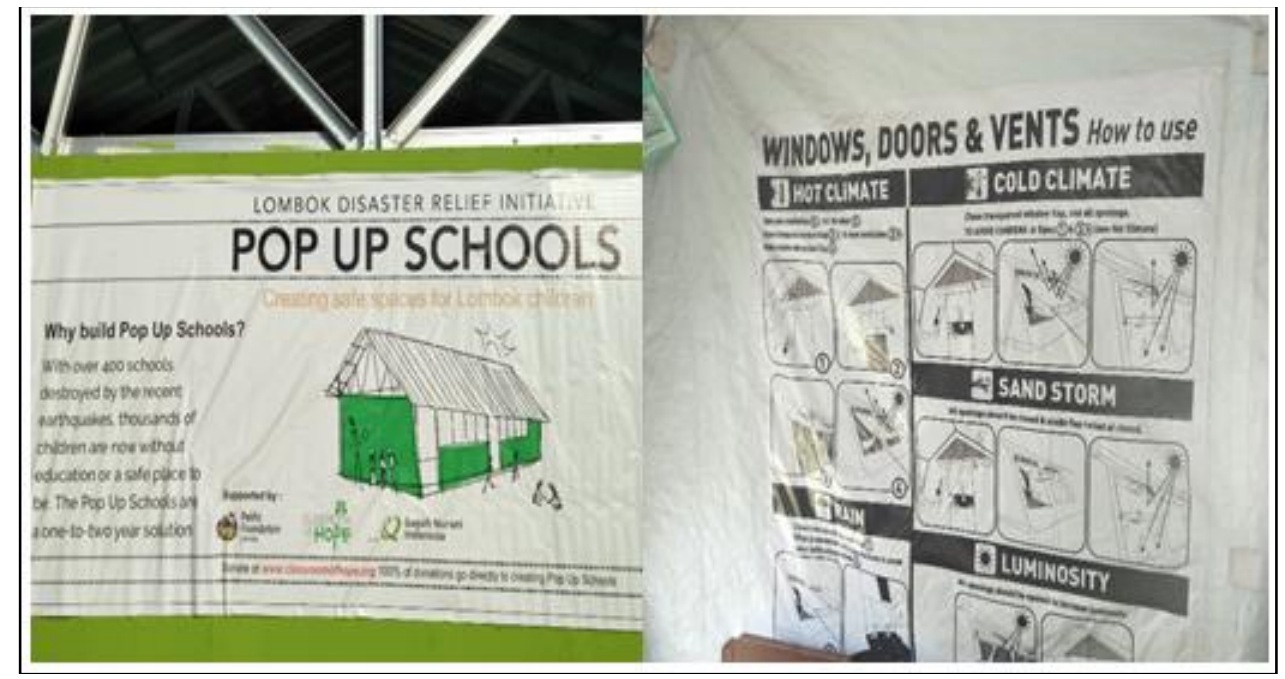

Figure 4. Adaptive Learning Guidance

Furthermore, the learning media development process was carried out by exploring the potentials that might be used as learning media based on local wisdom. It was done by making observations in the affected areas and conducting FGDs with several related parties, in order to obtain several important points related to how the post-disaster learning process is carried out. The results are then presented in an indicator which can be seen in Table 1. 
Table 1. Analysis of Needs and Potential of Disaster-Affected Areas

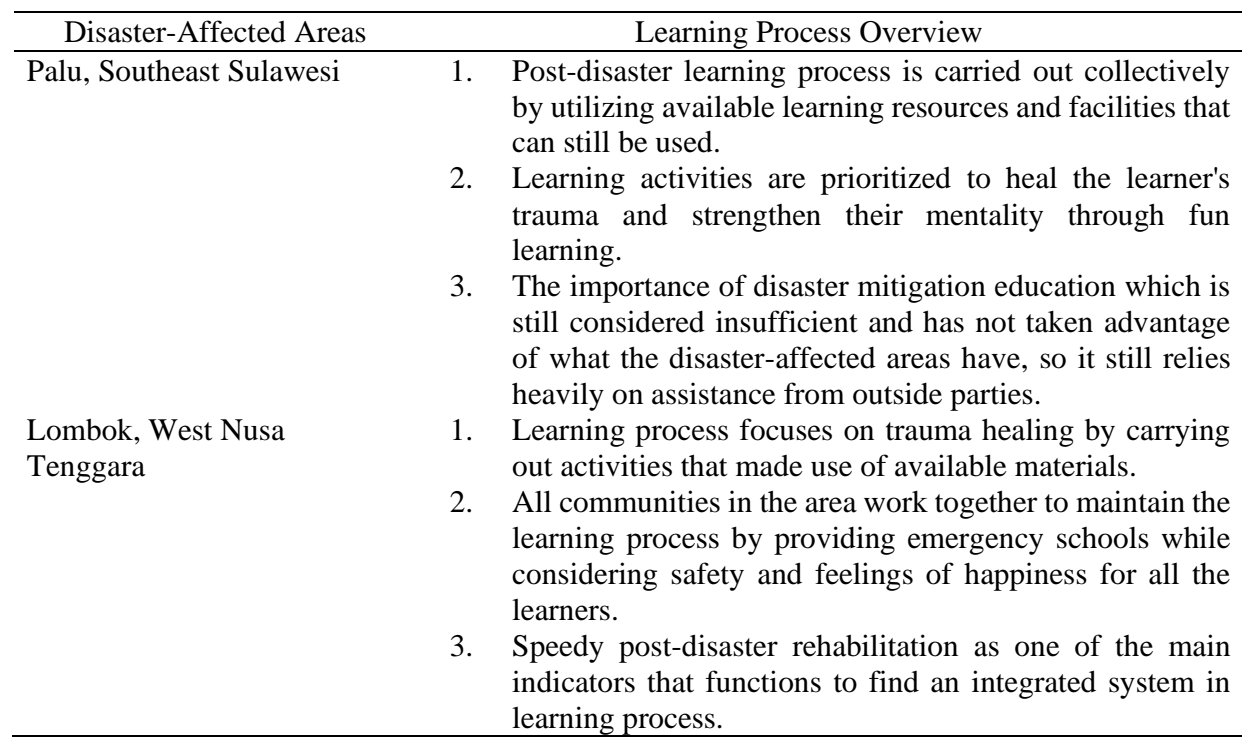

Table 1 describes some of the findings from observations, FGDs, and interviews with several related parties. If you look at the process carried out in restoring existing learning process, activities are carried out with a focus on the positive changes in the child's mental which are predicted to be very important and this should be put forward in post-disaster management. The researchers conducted further analysis to find effective learning designs that could be used after a disaster which can be seen in Table 2.

Table 2. Post-Disaster Learning Design

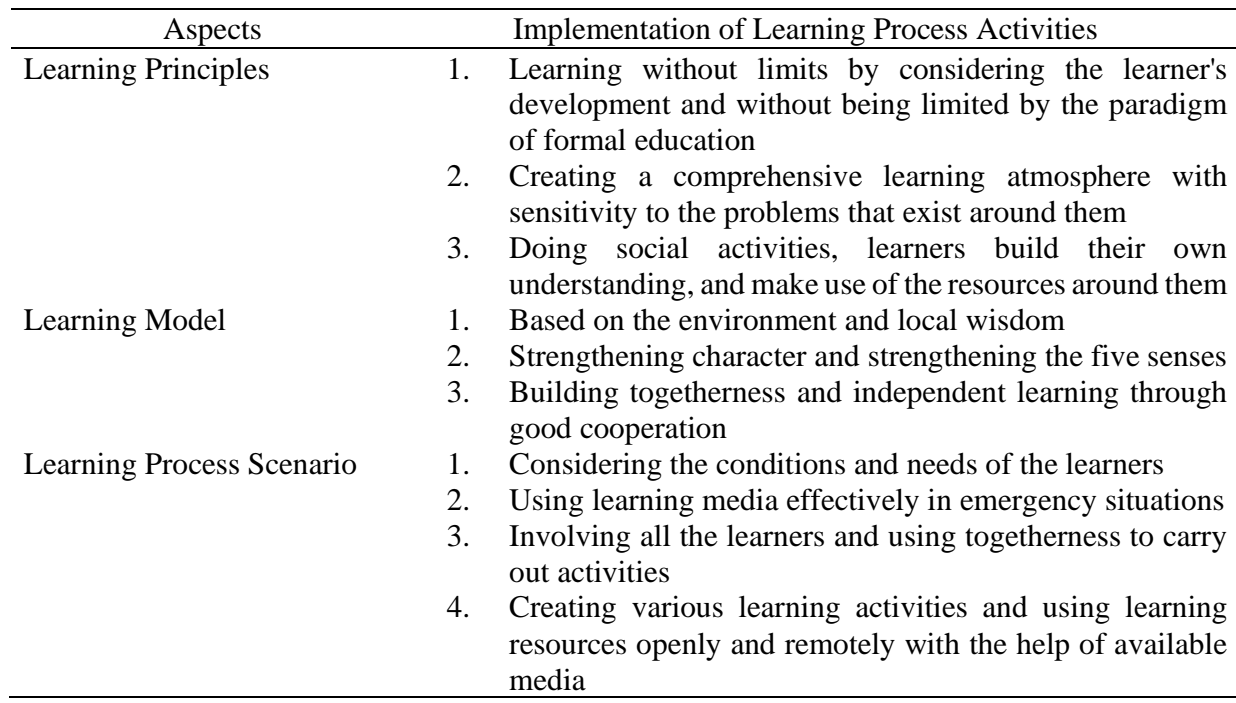

Table 2 explains what kind of lesson plans might be possible in post-disaster affected areas. This design is certainly based on in-depth exploration of the advantages and disadvantages that may be found in the post-disaster affected areas. In addition, it is possible for learning activities to form a study group that is divided based on the characteristics that best suit the learner's condition in the field. The concept of a post-disaster study group can be seen in Table 3 . 
Table 3. Post-Disaster Learning Process Groupings

\begin{tabular}{|c|c|c|}
\hline No & Types of Study Groups & Description \\
\hline 1 & Small Homogeneous Group & $\begin{array}{l}\text { Fewer than } 10 \text { learners with similar education levels are } \\
\text { accompanied by one or two adults }\end{array}$ \\
\hline 2 & Small Heterogeneous Group & $\begin{array}{l}\text { Fewer than } 10 \text { learners with various educational levels are } \\
\text { accompanied by one or two adults }\end{array}$ \\
\hline 3 & Medium Homogeneous Group & $\begin{array}{l}\text { 10-30 learners with almost the same education level are } \\
\text { accompanied by one or two or more adults }\end{array}$ \\
\hline 4 & Medium Heterogeneous Group & $\begin{array}{l}10-30 \text { learners with various education levels are } \\
\text { accompanied by one or two or more adults }\end{array}$ \\
\hline 5 & Large Homogeneous Group & $\begin{array}{l}\text { Over } 30 \text { learners with almost the same education level are } \\
\text { accompanied by one or two or more adults }\end{array}$ \\
\hline 6 & Large Heterogeneous Group & $\begin{array}{l}\text { Over } 30 \text { learners with various educational levels are } \\
\text { accompanied by one or two or more adults }\end{array}$ \\
\hline
\end{tabular}

Table 3 describes the grouping of study groups that might be formed after a disaster. The grouping is of course adjusted to the characteristics of the existing development in the learners so that the hope is that in post-disaster conditions, they can return to good emotions and survive better. Learning topics that can be done in the group can also vary greatly depending on what the they have in exploring their environment while being given directions by the supervisors who participate in the learning process.

Disaster is something that we cannot predict in advance. This situation can occur at any time without preparation and without planning, so what can be done is a process of anticipation and proper handling after the disaster occurs. Post-disaster learning process is an activity that should be implemented and used as a teaching subject, especially for disaster-prone areas. According to Mitani (2019), post-disaster learning process teaches the learners how they can survive and rise to achieve their dreams. Post-disaster learning process always prioritizes the value of local wisdom, meaning that everything in the disaster-affected areas must be a top priority as learning resources.

Post-disaster learning process certainly requires many parties to support one another. As found in this study, learning process can take place when many parties help one another in compliance with their respective competencies. The government as the main party with a centralized policy must be able to see learning process as an important aspect so that when a disaster occurs, they have prepared various things to restore it. The government must also provide targeted coordination so that the implementation of post-disaster learning process can be done optimally. In addition, there needs to be assistance from voluntary organizations and other communities that usually provide human resources to help restore the disaster-affected areas. These parties must become partners with the community to support post-disaster learning process (Fekete et al., 2020; Keating and Hanger-Kopp, 2020; Lightfoot, Lesen and Ferreira, 2020).

The study provides a disaster learning process framework that focuses on several key points. First, that the development of post-disaster learning process must prioritize the psychological and physical condition of the learners running normally. It means that the learners must be in the best and most pleasant condition because it will bring them to a high awareness to continue living and growing properly. Second, learning process must be based on the optimization of the disaster-affected areas. Utilizing all available resources at the disaster-affected areas is an important thing in implementing post-disaster learning process. The remaining natural resources must be optimized and used as learning resources, while the people in the disaster area can be the parties who help facilitate the learning process. Another side that must also be an important consideration for policy makers and researchers in the future is how to create a learning model that can be online based because this will be much more helpful, especially in conditions like the one we are currently facing. Furthermore, post-disaster learning process must also consider the use of effective study groups which are predicted to be one of the important activities that are effectively carried out. In addition, by considering the various other existing media, both those supported by outsiders, it will help spark motivation and diversity of activities to be more interesting. Thus, post-disaster learning process must consider these things. 


\section{CONCLUSION}

The sustainability of the learners affected by disasters needs special attention. Through post-disaster learning process, they learn by grouping themselves into groups according to the level of needs required. The learning process is fulfilled by using various instruments such as textbooks, props, and other objects around, as well as carrying out various activities such as trauma healing, playing, exercising, telling stories, and watching educational and entertainment shows. In addition, the post-disaster learning model that is implemented includes the principles of independence, openness, and distance learning where all activities involve the closest community as parties who will encourage the learners and of course jointly get happiness by doing these activities.

\section{ACKNOWLEDGEMENT}

This study was conducted as a collaboration between Universitas Terbuka lecturers and researchers at the Center for Curriculum and Books of Ministry of Education and Culture of the Republic of Indonesia. Our highest appreciation goes to the Institute for Research and Community Service (LPPM) of the Universitas Terbuka for funding this study. We also thank all respondents who participated in this study.

\section{REFERENCES}

Dewy, C. (2018) 'Model pembelajaran berbasis masalah untuk mengatasi keterbatasan sumber belajar geografi pada pembelajaran kelas darurat pasca bencana sinabung', Jurnal Kapita Selekta Geografi, 1(September), pp. 39-45.

Fekete, A. et al. (2020) 'Pathways for advancing integrative disaster risk and resilience management in Iran: Needs, challenges and opportunities', International Journal of Disaster Risk Reduction, 49. doi: 10.1016/j.ijdrr.2020.101635.

Forbes, D., Creamer, M. and Wade, D. (2012) 'Psychological support and recovery in the aftermath of natural disaster', International Psychiatry, 9(1), pp. 15-17. doi: DOI: 10.1192/S1749367600002939.

Gall, M. D., Borg, W. R. and Gall, J. P. (1996) Educational research: An introduction. 6th edition. Longman Publishing.

Hemsley, G., Holm, A. and Dodd, B. (2013) 'Conceptual distance and word learning: Patterns of acquisition in Samoan-English bilingual children', Journal of Child Language, 40(4), pp. $799-820$. doi: $10.1017 /$ S0305000912000293.

Issa, F. S. et al. (2019) 'Effectiveness of children's disaster risk reduction (DRR) program on earthquake preparedness in Jordan', Prehospital and Disaster Medicine, 34(s1), pp. s42-s43. doi: 10.1017/s1049023x1900102x.

James, J. J. (2014) 'Education and training: Integrating the disaster cycle', Disaster Medicine and Public Health Preparedness, 8(4), p. 279. doi: 10.1017/dmp.2014.86.

Joseph, D. (2004) 'Methodological alignment in design-based research', Educational Psychologist, 39(4), pp. $203-212$. doi: $10.1207 / \mathrm{s} 15326985 \mathrm{ep} 3904$.

Keating, A. and Hanger-Kopp, S. (2020) 'Practitioner perspectives of disaster resilience in international development', International Journal of Disaster Risk Reduction, 42, p. 101355. doi: 10.1016/j.ijdrr.2019.101355.

Kusmaryono, I. (2012) 'Pengembangan pembelajaran matematika kontekstual edutainment berbasis budaya lokal di daerah bencana', in Makalah Seminar Kemdikbud Dikti 'Designing Quality Learining Landscape in Indonesia', pp. 1-14.

Li, S.-J., Wu, C. S. T. and Wong, H. T. (2016) 'School safety and children health in a post-disaster community: Implications to collaborative care and service learning in school health', Journal of Acute Disease, 5(1), pp. 46-50. doi: 10.1016/j.joad.2015.08.005.

Lightfoot, E. S., Lesen, A. E. and Ferreira, R. J. (2020) 'Gender and resilience in Gulf Coast communities: Risk and protective factors following a technological disaster', International Journal of Disaster Risk Reduction, 50, p. 101716. doi: 10.1016/j.ijdrr.2020.101716.

Mitani, S. (2019) 'Learning effects of cross road game using a clicker-nano system', Prehospital and Disaster Medicine, 34(s1), pp. s145-s146. doi: 10.1017/s1049023x19003236.

Pek, J. H., Kang, H. M. and Anantharaman, V. (2019) 'Teaching disaster site medical support in Indonesia', Disaster Medicine and Public Health Preparedness, pp. 1-6. doi: 10.1017/dmp.2019.134.

Prakoso, B. H., Ramadani, Z. and Rahmah, B. (2020) 'Best Pratices of Character Education in Leading Schools in Bandung', Indonesian Journal of Educational Assesment, 3(1), p. 61. doi: 10.26499/ijea.v3i1.61. 
Putri, N. A. E., Sanjoto, T. B. and Sriyanto (2018) 'Pendidikan mitigasi bencana tsunami dengan menggunakan media pembelajaran buku saku pada masyarakat pesisir desa karanggadung kecamatan petanahan kabupaten kebumen', Edu Geography, 6(1), pp. 72-79. Available at: http://journal.unnes.ac.id/sju/index.php/edugeo.

Rahman, F. and Umam, Q. (2018) 'Sena Sakti ( Sekolah Bencana; Siaga, Aksi dan Mitigasi )', Jurnal Ilmiah Ilmu Sosial, 4(1), pp. 6-11.

Ramdani, Z., Amrullah, S. and Felisima Tae, L. (2019) 'Pentingnya Kolaborasi dalam Menciptakan Sistem Pendidikan yang Berkualitas', MediaPSI, 5(1), pp. 40-48. doi: 10.21776/ub.mps.2019.005.01.4.

Robertson, B. W. et al. (2019) 'Using a combination of human insights and "deep learning" for real-time disaster communication', Progress in Disaster Science, 2, p. 100030. doi: 10.1016/j.pdisas.2019.100030.

Rusilowati, A. and Binadja, A. (2012) 'Mitigasi bencana alam berbasis pembelajaran bervisi science environment technology and society', Jurnal Pendidikan Fisika Indonesia, 8(1), pp. 51-60. doi: 10.15294/jpfi.v8i1.1994.

Steinert, C. et al. (2017) 'Psychodynamic therapy: As efficacious as other empirically supported treatments? A meta-analysis testing equivalence of outcomes', American Journal of Psychiatry, 174(10), pp. 943-953. doi: 10.1176/appi.ajp.2017.17010057.

Susiana, S. (2018) 'Peran pemerintah daerah dalam penyelenggaraan kesehatan reproduksi (Studi di provinsi jawa tengah dan provinsi kalimantan barat)', Jurnal Aspirasi, 7(1), pp. 1-16. doi: 10.22212/aspirasi.v7i1.1084.

Tae, L. F., Ramdani, Z. and Shidiq, G. A. (2019) 'Analisis tematik faktor-faktor yang mempengaruhi keberhasilan siswa dalam pembelajaran sains', Indonesian Journal of Educational Assesment, 2(1), p. 79. doi: 10.26499/ijea.v2i1.18.

Thurston, W. E. et al. (2017) 'Disaster management and farm family mental mealth: The BSE crisis as a case study', Prehospital and Disaster Medicine, 32(S1), pp. S185-S186. doi: 10.1017/s1049023x17004927.

Tsujiguchi, T. et al. (2019) 'The development of an active learning program for the medical responders in a nuclear disaster', Disaster Medicine and Public Health Preparedness, 13(5-6), pp. 853-858. doi: 10.1017/dmp.2018.168.

Wang, F. and Hannafin, M. J. (2005) 'Technology-enhanced learning environments', ETR\&D, 53(4), pp. 5-23. 